\title{
EMERGING MATERIALS FOR SOLAR CELL APPLICATIONS
}

FIRST QUARTER REPORT

FOR PERIOD FEBRUARY 15 - MAY 31, 1979

\author{
ROBERT L. ROD \\ ZVI SHKEDI \\ RONALD BUNSHAH \\ OSCAR STAFSUDD
}

JUNE 15, 1979

\section{MONOSOLAR, Inc. \\ a subsidiary of \\ Monogram Industries, Inc.}

Suite 600

100 Wilshire Blvd.

Santa Monica, CA 900401

\author{
PREPARED FOR THE \\ U.S. DEPARTMENT OF ENERGY \\ SOLAR ENERGY \\ UNDER CONTRACT DOE-ET-78-D-04-0039
}




\section{DISCLAIMER}

This report was prepared as an account of work sponsored by an agency of the United States Government. Neither the United States Government nor any agency Thereof, nor any of their employees, makes any warranty, express or implied, or assumes any legal liability or responsibility for the accuracy, completeness, or usefulness of any information, apparatus, product, or process disclosed, or represents that its use would not infringe privately owned rights. Reference herein to any specific commercial product, process, or service by trade name, trademark, manufacturer, or otherwise does not necessarily constitute or imply its endorsement, recommendation, or favoring by the United States Government or any agency thereof. The views and opinions of authors expressed herein do not necessarily state or reflect those of the United States Government or any agency thereof. 


\section{DISCLAIMER}

Portions of this document may be illegible in electronic image products. Images are produced from the best available original document. 


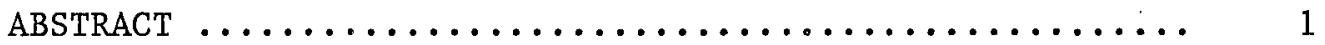

I. INTRODUCTION $\ldots \ldots \ldots \ldots \ldots \ldots \ldots \ldots \ldots \ldots \ldots \ldots \ldots \ldots$

II. PROGRAM STATUS $\ldots \ldots \ldots \ldots \ldots \ldots \ldots \ldots \ldots \ldots \ldots \ldots \ldots$

A. Monosolar $\ldots \ldots \ldots \ldots \ldots \ldots \ldots \ldots \ldots \ldots \ldots \ldots, 4$

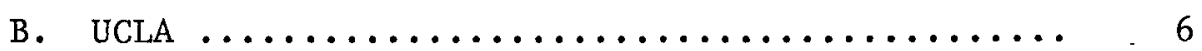

III. CHARACTERIZATION $\ldots \ldots \ldots \ldots \ldots \ldots \ldots \ldots \ldots \ldots \ldots \ldots . \ldots \ldots$

A. Electrical $\ldots \ldots \ldots \ldots \ldots \ldots \ldots \ldots \ldots \ldots \ldots \ldots \ldots$

B. Structural $\ldots \ldots \ldots \ldots \ldots \ldots \ldots \ldots \ldots \ldots \ldots \ldots, 17$

IV. PREPARATION OF TRANSPARENT CONDUCTING OXIDE FILMS . 26

V. WORK PROPOSED DURING UPCOMING QUARTER $\ldots \ldots \ldots \ldots \ldots . . .26$

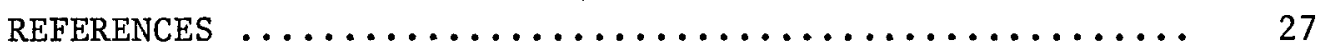

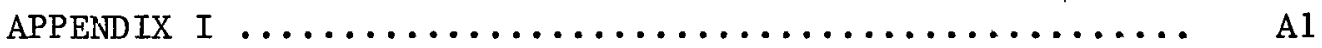




\section{ABSTRACT}

Work reported upon herein is a continuation of earlier efforts directed by Monosolar to develop the theory controlling the electroplating of a compound semiconductor on a transparent, conductive substrate and to demonstrate operative solar cells using the approach. The current program now underway involves Monosolar and its newly selected subcontractor, UCLA, and is divided essentially into three paralleled team efforts. The first effort centers on refining the electroplating process at Monosolar so thicker and more uniform layers of $\mathrm{p}$ - or n-type cadmium telluride can be plated on both $\operatorname{In}_{2} \mathrm{O}_{3}: \mathrm{Sn}$ - and Ni- coated substrates. $1 \mu \mathrm{M}$ thick polycrystalline films have been achieved for the first time ever without peeling problems, a thickness optimum for maximum solar absorption and economy of materials. Second, work is underway at UCLA to physically and electrically characterize the films and diodes made from them. Under proper conditions Schottky diodes with better than $10^{4}$ rectification ratios at $1.5 \mathrm{~V}$ were obtained along with preliminary indications of grain sizes up to $1 \mu \mathrm{M}$. Measurements of these diodes revealed the presence of deep trapping level(s) that may be associated with plating process impurities that since may have been eliminated. Third, work so far on developing improved techniques for depositing ITO has been successful at UCLA in their effort to eliminate persistent problems with ITO obtained from outside suppliers serving the less demanding liquid crystal display (LCD) industry. 


\section{INTRODUCTION}

This report describes work during the first quarter of an effort under DOE's emerging solar cell materials program. Specific research tasks include fabricating electroplated $2.5 \times 2.5 \mathrm{~cm}^{2}$ ITO/CdTe solar cells whose efficiency is unaffected by the presence, if any, of pinholes and then making such physical and electrical characterizations as are needed to evaluate the technique's variables. The work will add to the knowledge gained by Ionosolar in its five-year long effort to fully reduce to practice its method for electroplating compound semiconductor solar cells.

Heretofore major attention has been devoted to developing the electrochemical theory underlying the formation of compound semiconductors films by plating and to making small relatively crude solar cells that have exhibited efficiencies in the order of $2 \%$. In the current program, a major effort is being expended to improve upon and characterize the CdTe films both physicalIy and electrically as a prelude to examining complete cells as a function of processing parameters.

In a paralleled effort, an in-house capability for applying ITO to either glass or to the CdTe itself is being developed. ITO-coated glass ordered from outside vendors mainly to the LCD industry has proven to be of inadequate quality for solar cell applications.

To accomplish the work required under the present DOE contract, Monosolar, Inc. has augmented its own in-house technical staff. Dr. Zvi Shkedi, most recently a solar cell research fellow at Brown University under Dr. Joseph Loferski, has joined Dr. Robert L. Rod of Monosolar as a coprincipal investigator. To perform various characterizations of materials and devices, and to develop a better method of applying ITO, Monosolar 
commissioned the University of California - Los Angeles as its subcontractor. Co-principal investigators at UCLA are Dr. Ronald Bunshah of the Material Science Department and Dr. Oscar Stafsudd of the Electrical Sciences and Engineering Department. Dr. Bunshah assisted by Dr. Prem Nath, a postdoctoral fellow with extensive solar cell and ITO background, is responsible for physical aspects of films and their evaluations, while Dr. Stafsudd is assisted by Bulent Basol, a graduate student performing electrical characterizations.

\section{PROGRAM STATUS}

In mid-February, 1979, when formal activities on behalf of DOE once again started, it was agreed upon by the participants that $100 \%$ of the initial effort would be devoted to achieving thicker, non-peeling pin-holefree films of. CdTe on both purchased ITO on glass substrates and on thin films of nickel evaporated over glass slides by UCLA and outside vendors. The erratic quality of purchased ITO necessitated the paralleled effort to plate CdTe on nickel, a decision that subsequent events proved to be a very wise one.

Being much more uniform, the nickel substrate approach very quickly demonstrated that previous problems with peeling of CdTe films, pinholes, and a general inability to achieve anywhere close to $1 \mu \mathrm{M}$ film thickness were directly attributable to yet unknown problems with purchased ITO substrates. At this writing CdTe films up to $1 \mu \mathrm{M}$ thick free from pinholes and peeling problems routinely are plated on nickel-coated glass subtrates at Monosolar under controlled plating conditions. Major plating parameters include an electrolyte of $\mathrm{CdSO}_{4}$ plus acid with a $\mathrm{pH}$ of about 2, a plating 
temperature of $90^{\circ} \mathrm{C}$, and the two anode approach (Te plus an inert one) as described in our previous reports to DOE under Contract No. E(49-18)-2457.

The departure to using nickel as a substrate may or may not be continued into the next upcoming phase of the program which requires fabrication of ITO/CdTe devices. Depending upon the success of paralleled work at UCLA developing an improved method for deposition of ITO, Monosolar may decide to continue improving upon its earlier heterojunction n-ITO/p-CdTe configuration wherein the ITO is coated on glass and a suitable back ohmic contact must be devised for the $\mathrm{p}$-CdTe, or it may favor some other cell configuration wherein the ITO is applied to a CdTe layer on Ni afterwards as a light-transparent "front" ohmic contact. In the latter case, the Ni will serve only as the ohmic contact. We are reserving judgement on which of these or other approaches will be evaluated in the coming months until on-going characterizations of layers are completed.

For convenience in reporting, the remainder of this particular section of the report dealing with program status will be broken down into separate paragraphs outlining the contributions of Monosolar and of UCLA:

A. Monosolar - The first three months of the program essentially were devoted to a number of electrochemical process refinements and improvements, some of which are still being implemented. Plating baths and solution filtration systems were upgraded to eliminate obvious sources of contamination, while more careful methods of purifying the electrolyte were devised. The level of tellurium dissolved in the electrolyte was measured to be in the order of $4 \mathrm{mg} / 1$ on the average, but possibly troublesome variations were noted during the time a cell was being plated. Means for holding this concentration constant are now being implemented in one of several on-going efforts to fix and thereafter control the Cd-Te stoichiometry. 
Attention was given also to upgrading process water quality that heretofor was deionized with a rating of 18 meghoms achieved by ion-exchange. This apparently is insufficient, and a just installed al1 glass and Teflon Corning distillation still and condenser system is now in operation. Auger measurements of Monosolar's CdTe films performed at SERI recently identified a wide range of contaminants, a group of which like $\mathrm{Ca}, \mathrm{Cl}$, and $\mathrm{Mg}$ most likely are water-borne and should not be present in newer film samples now being made with distilled water in the electrolyte. The primary effect of contamination is to degrade the electronic/semiconductor characteristics of diodes (and cells) made in this type of plating system. Problems with peeling of films is a function of a number of factors, a major one being cleanliness of the substrate. Improvements in cleaning procedures and optimization of plating current have enabled Monosolar to plate films without peeling up to thicknesses around $1 \mu \mathrm{M}$, the desired end-point value. Control of the electroplating "rest potential" determines not only the 'p-ness' or 'n-ness' of the CdTe; as our theory shows, but CdTe grain size also. Correlations between such process variables and the physical and electrical characterizations for various films is proceeding very well at this writing. The next problem lying immediately ahead is a study of the resistivity. of the CdTe films. Present indications show figures around $10^{5} \mathrm{ohms} \cdot \mathrm{cm}$ which pinpoints a possible need for subsequent anneal of the plated films and/or optimization of the co-deposition dopant processes for making n-type CdTe with In and p-type with As. In combination with developing good ohmic contacts to the films, the annealing possibilities are now under active investigation and will be discussed in the next quarterly report. 
B. UCLA - Work accomplished at UCLA during the first quarter of the program was two-fold, investigation of thin films, including ITO growth by a new technique, and evaluation of electroplated CdTe films supplied by Monosolar. At the same time, considerable attention was directed to what type of device structure configurations would best serve the objective of tieing solar cell performance to production parameters.

The basic device structure of previous years at Monosolar/USC ${ }^{(1)}$ was $\mathrm{n}-\mathrm{In}_{2} \mathrm{O}_{3}: \mathrm{Sn} / \mathrm{p}-\mathrm{CdTe}: \mathrm{As} / \mathrm{Te}$. Low rectification ratios and high leakage currents associated with these early diodes did not permit usual electrical measurements giving valuable information about film characteristics and device performance. Such information is essential in understanding operation of the solar cell itself and its theoretical modelling.

In the current work, some modification of the basic plated layer structure was agreed upon in order to carry out evaluations of the electrical properties of the CdTe layers. CdTe films were plated directly on metallized glass slides rather than the ITO-coated glass substrates normally used. The metallization was vacuum deposited and consisted of a $100-200 \AA$ chromium layer followed by a $1 \mu \mathrm{M}$ layer of nickel. CdTe films approximately $0.8 \mu \mathrm{M}$ thickness were plated thereafter at Monosolar for most of the evaluation work at UCLA. Thicker layers will be useful shortly for other work.

Freshly plated samples were rinsed in deionized water and blown dry. Aluminum dots $\left(2 \mathrm{~mm}^{2}\right)$ were then evaporated on the CdTe at UCLA through a shadow mask in a vacuum of about $2 \times 10^{-6}$ torr. Silver epoxy paint then was used to bond lead wires to the Al contact dots. Diodes formed by this structure then were electrically characterized with results as shown herein. 
Simultaneously with the evaluation of films and devices produced by Monosolar, UCLA undertook a ground-up investigation of ITO. A new technique was devised for applying ITO. The promising progress achieved by UCLA is given in Appendix I to this quarterly report. At some opportune time in a month or so, Monosolar will commence work plating CdTe on ITO films produced at UCLA and will compare results with ITO films supplied by PPG and other suppliers.

\section{CHARACTERIZATION}

\section{A. Electrical}

1. I-V Characteristics*

Diodes were prepared on films plated at different potentials and a correlation between the rectification ratios and the plating potential was established. One important observation was the change in the characteristics of the devices made on the same slide. Usually the diodes closest to the surface of the plating solution nearest to the contact clamps attached to the power supply are better as far as the rectification is concerned. Table I and Fig. 1 show the forward current observed at $1.5 \mathrm{~V}$ for diodes made on films prepared at different plating potentials for typical devices on each slide. A more negative plating potential produces n-type material, a less negative voltage yields p-type.

*The devices reported in the following sections were made using films electroplated from Arsenic doped solutions. 


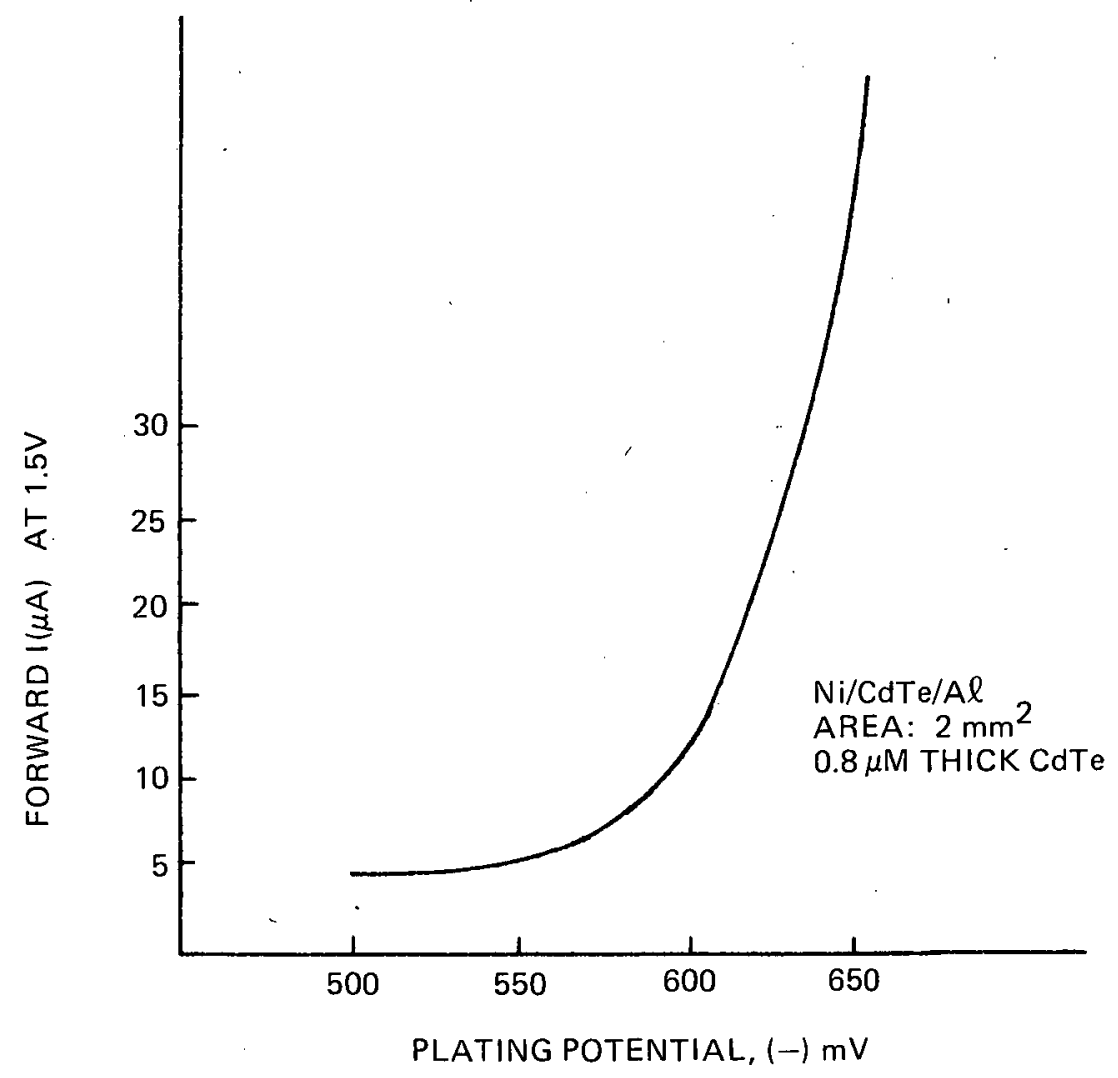

Figure 1. Diode Forward Current as a Function of CdTe Plating Potential. 


\begin{tabular}{|c|c|c|}
\hline Sample No. & $\begin{array}{c}\text { Plating } \\
\text { Potential }\end{array}$ & $\begin{array}{c}\text { Forward } \\
\text { Current at 1.5V }\end{array}$ \\
\hline R02 & $-660 \mathrm{mV}$ & $\sim 1.6 \mathrm{~mA}$ \\
R01 & $-645 \mathrm{mV}$ & $\sim 30 \mu \mathrm{A}$ \\
R04 & $-600 \mathrm{mV}$ & $\sim 10 \mu \mathrm{A}$ \\
R09 & $-550 \mathrm{mV}$ & $\sim 5 \mu \mathrm{A}$ \\
R05 & $-500 \mathrm{mV}$ & $\sim 5 \mu \mathrm{A}$ \\
\hline
\end{tabular}

DIODE CHARACTERISTICS AS A FUNCTION OF PLATING POTENTIAL

TABLE I

The best rectification ratios (better than $10^{4}$ at $1.5 \mathrm{~V}$ ) were obtained for the highest plating potential $(-660 \mathrm{mV})$. Fig. 2 is the I-V characteristics of a diode made on Sample R02. The current mechanism in the devices is being studied.

Breakdown voltages for the above devices were in the order of 3-4 volts. Under pulsed conditions, however, voltages as high as $20 \mathrm{~V}$ could be applied in the reverse direction without breakdown of the device. This observation of small breakdown voltages for D.C. measurements can be explained by the presence of deep trapping level(s) in the material as will be explained in the next section.

2. C-V Characteristics

Since the reverse currents of the diodes were less than $10^{-6} \mathrm{~A}$ up to $2-3 \mathrm{~V}$ reverse voltages, $\mathrm{C}-\mathrm{V}$ measurements could be made without introducing appreciable experimental error.

A capacitance bridge (General Radio type 716.C) was used. Steady state value of the capacitance was measured as a function of applied bias and frequency. Measurements at $1 \mathrm{MHz}$ were taken using a Boonton Electric 


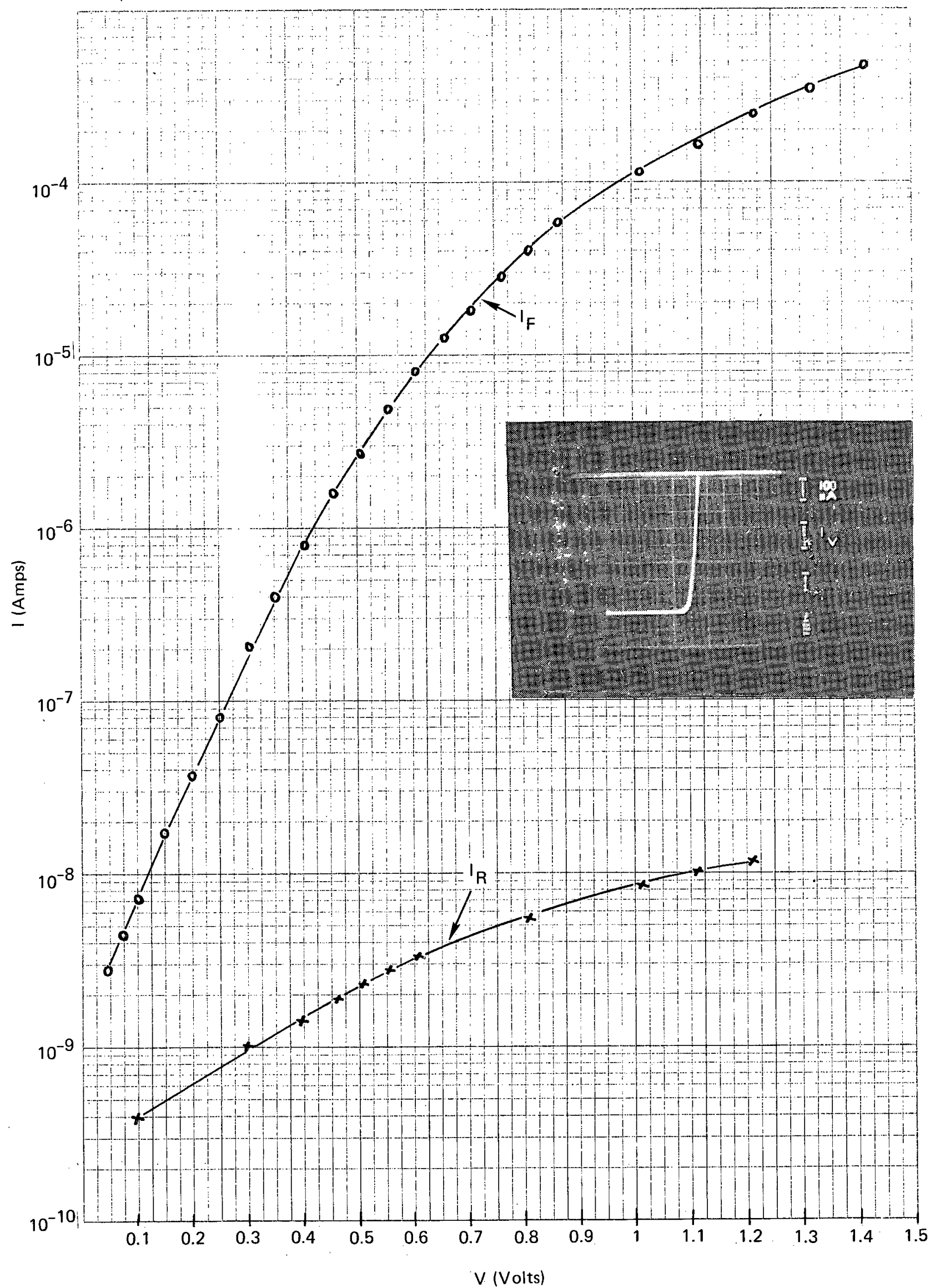

Figure 2. I-V Characteristics of Diode \# 4 
Capacitance Meter, Model 72A. C-V data for diode $\|_{4}$ of Fig. 2 is plotted in Fig. 3 for the frequency range of $1 \mathrm{KHz}-1 \mathrm{MHz}, 1 / \mathrm{C}^{2}$ as a function of voltage at different frequencies is also shown in Fig. 4.

There are two important points demonstrated by Figs. 3 and 4:

a. A change in the slope of $1 / \mathrm{C}^{2}$ as a function of voltage.

b. A strong dependence of $\mathrm{C}$ value on frequency at a given voltage.

Both features can be explained by the presence of trapping levels in the material ${ }^{(2)}$, as the following simple discussion suggests:

Fig. 5a, is the energy band diagram of a metal/semiconductor junction at zero bias. There is a deep donor type trapping leve1 at $\mathrm{E}_{\mathrm{T}}$. $E_{D}$ is the shallow donor energy level. Deep centers that are below the Fermi level are neutral since they are filled with electrons. Now, if a small forward voltage is applied and capacitance is measured at low frequencies (so that the shallow level can respond to the signal), the resulting capacitance would be only due to the shallow level because filled deep traps do not introduce any space charge.

$$
\text { i.e. } \quad c=\frac{\varepsilon A}{W} \text { where } W=\sqrt{\frac{2 \varepsilon\left(V_{D}-V\right)}{q_{N}^{+}}}
$$

where $\quad W=$ depletion layer width

$$
\begin{aligned}
A & =\text { area } \\
\varepsilon & =\text { dielectric constant } \\
\mathrm{V}_{D} & =\text { diffusion potential } \\
\mathrm{N}_{D}^{+} & =\text {ionized charge density due to shallow donors. }
\end{aligned}
$$




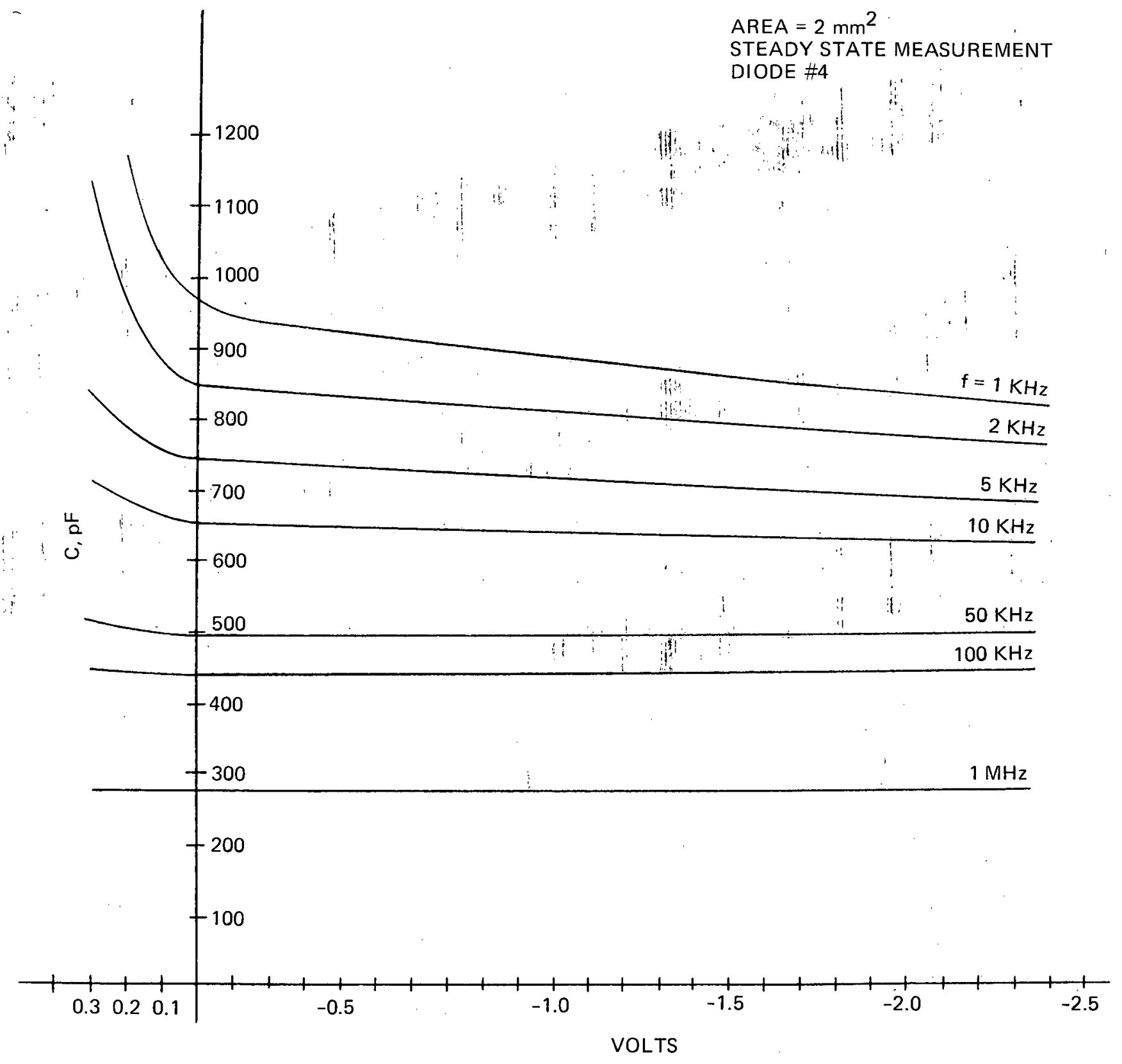

Figure 3. C-V Data for Diode \#4 


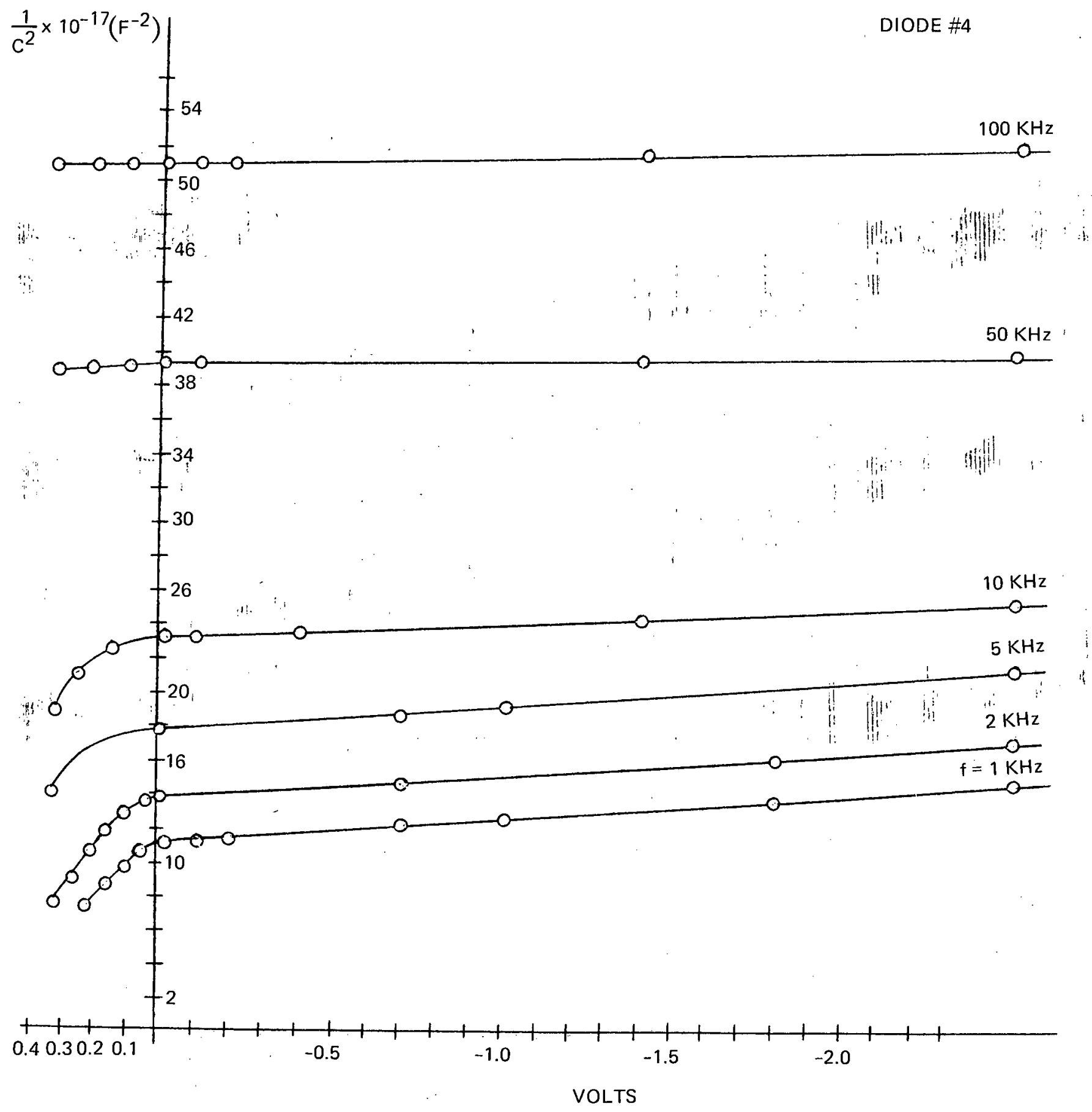

Figure 4. I/C $\mathrm{C}^{2}$ as a Function of Voltage for Diode $\#_{4}$ 


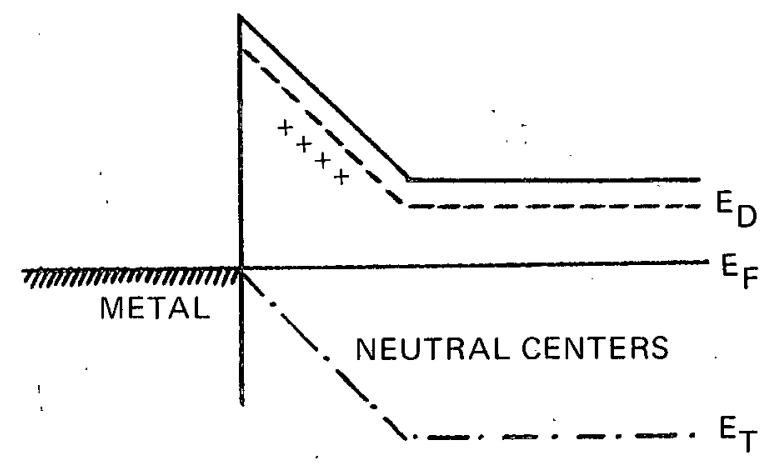

CHARGE

DENSITY, $\rho$

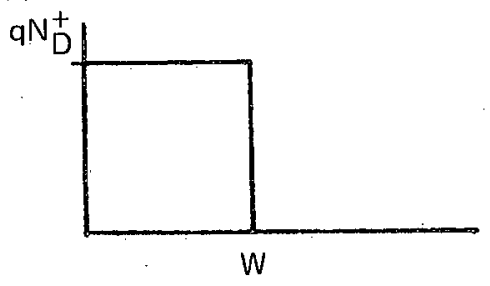

(a)
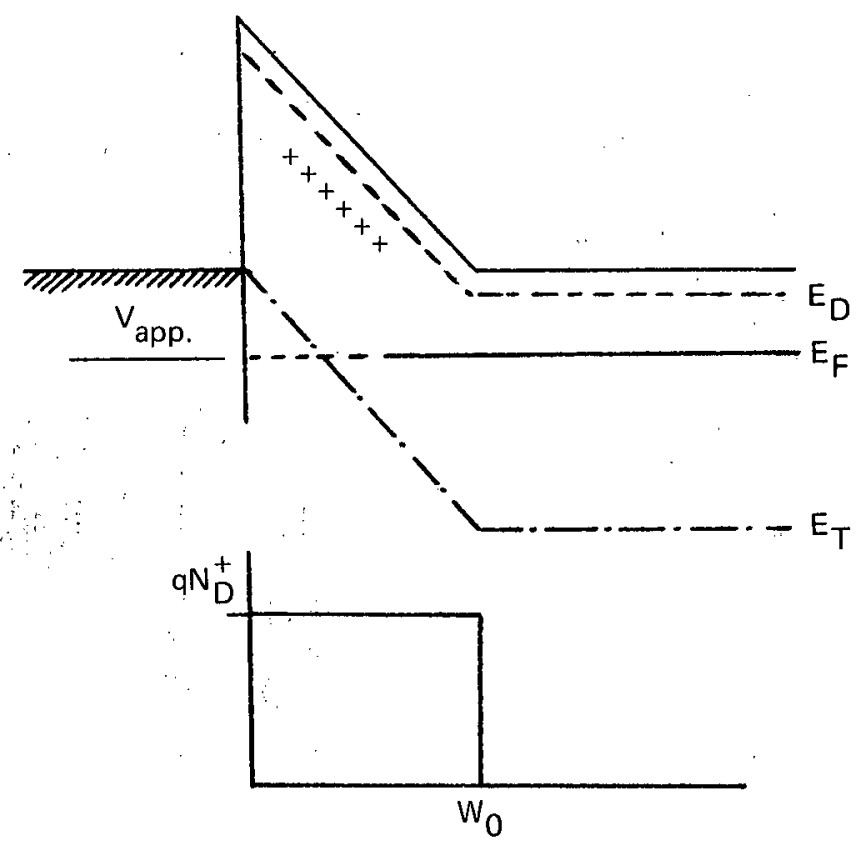

(b)

$$
t=0
$$

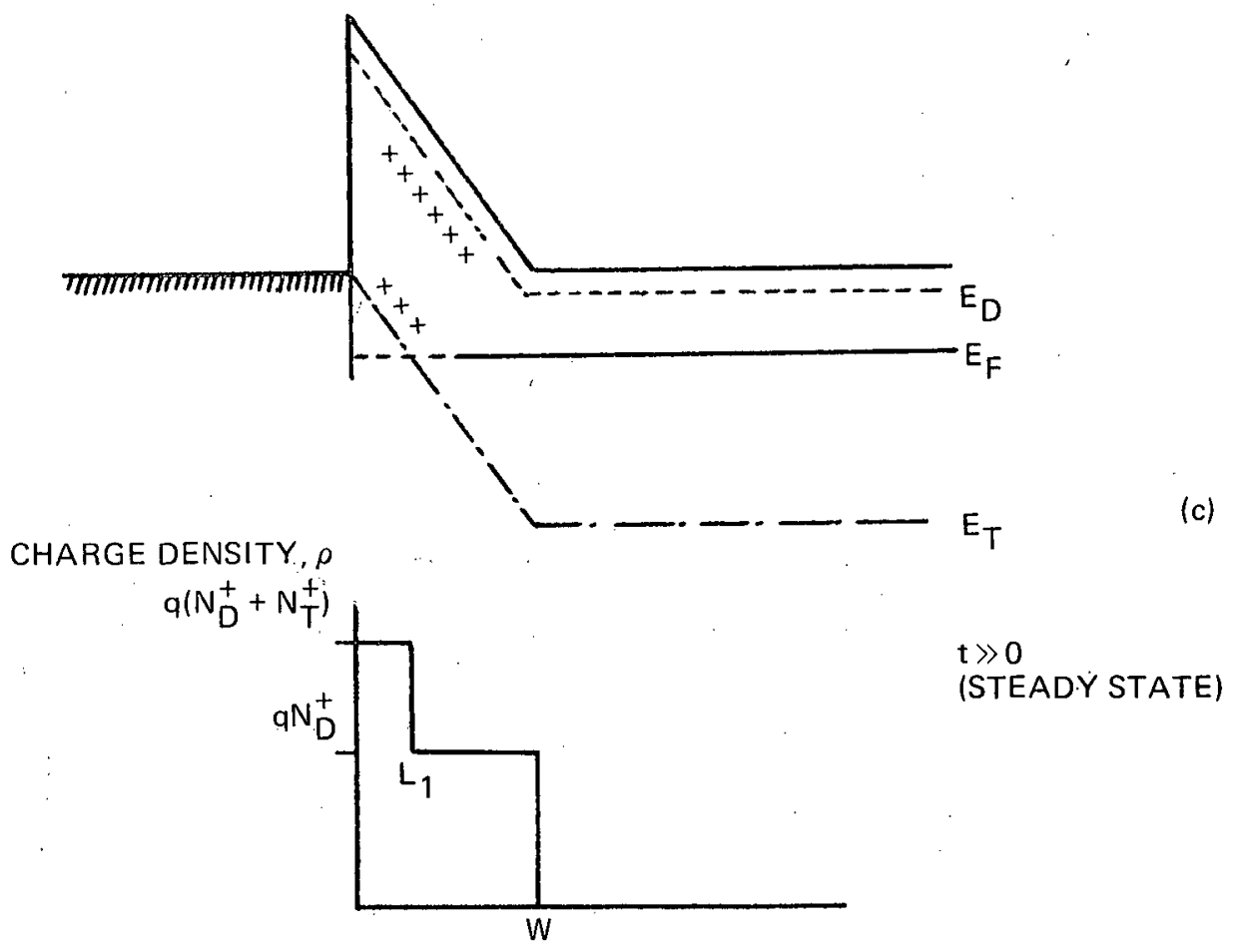

(c)

Figure 5. Energy Band Diagram - Metal/Semiconductor Junction 
So $1 / \mathrm{C}^{2}$ as a function of $\mathrm{V}$ must be linear, and the slope must be inversely proportional to $\mathrm{N}_{\mathrm{D}}^{+}$. We observe this kind of behavior in Fig. '4. The slope of the linear region for $\mathrm{f}=1 \mathrm{KHz}$ curve gives an ionized charge density of about $10^{16} / \mathrm{cm}^{3}$. The intersection point with the voltage axis gives a value of $\mathrm{V}_{\mathrm{D}} \approx 0.55 \mathrm{~V}$, which is in agreement. with the turn-on voltage observed for the diodes.

Now suppose that a reverse bias is applied to the above diode at $t=0$. The depletion region will first go to $W_{0}$, then start to collapse back as the deep levels that are above the Fermi level release their electrons thus contributing to the space charge (Figs. $5 b$ and $5 c$ ).

Using Poisson's equation one can show that steady state capacitance $\mathrm{C}_{\mathrm{si}}$ is given by the formula ${ }^{(3)}$,

$$
\frac{1}{\mathrm{C}_{\mathrm{SS}}^{2}}=\frac{2}{\mathrm{qN}_{\mathrm{D}}^{+} \varepsilon}\left[\mathrm{V}_{\mathrm{D}}+\mathrm{V}_{\mathrm{R}}-\frac{\mathrm{qIN}_{\mathrm{T}}^{+} \ell_{1}^{2}}{2 \varepsilon}\right]
$$

where $\mathrm{IN}_{\mathrm{T}}^{+}$is the ionized trap charge density.

According to the above equation, in the presence of deep levels, the slope of the $1 / \mathrm{C}^{2}$ vs. $\mathrm{V}$ curve will be decreased by an amount $\mathrm{N}_{\mathrm{T}}^{+} e_{1}^{2} / \mathrm{N}_{\mathrm{D}}^{+} \varepsilon^{2}$ for reverse voltages that are high enough to cause emptying of deep levels. This is the kind of behavior we observe in Fig. 4. The extra space charge due to the deep levels also explains the low breakdown voltages found in D.C. measurements for those diodes. The high field region right next to the barrier metal can cause the observed behavior.

A transient capacitance measurement was also made showing the rate at which the depletion region collapses back after application of a reverse bias. Fig. 6 shows such a capacitance transient with a time constant of $20 \mathrm{sec}$. which is reasonable for deep slow centers. 

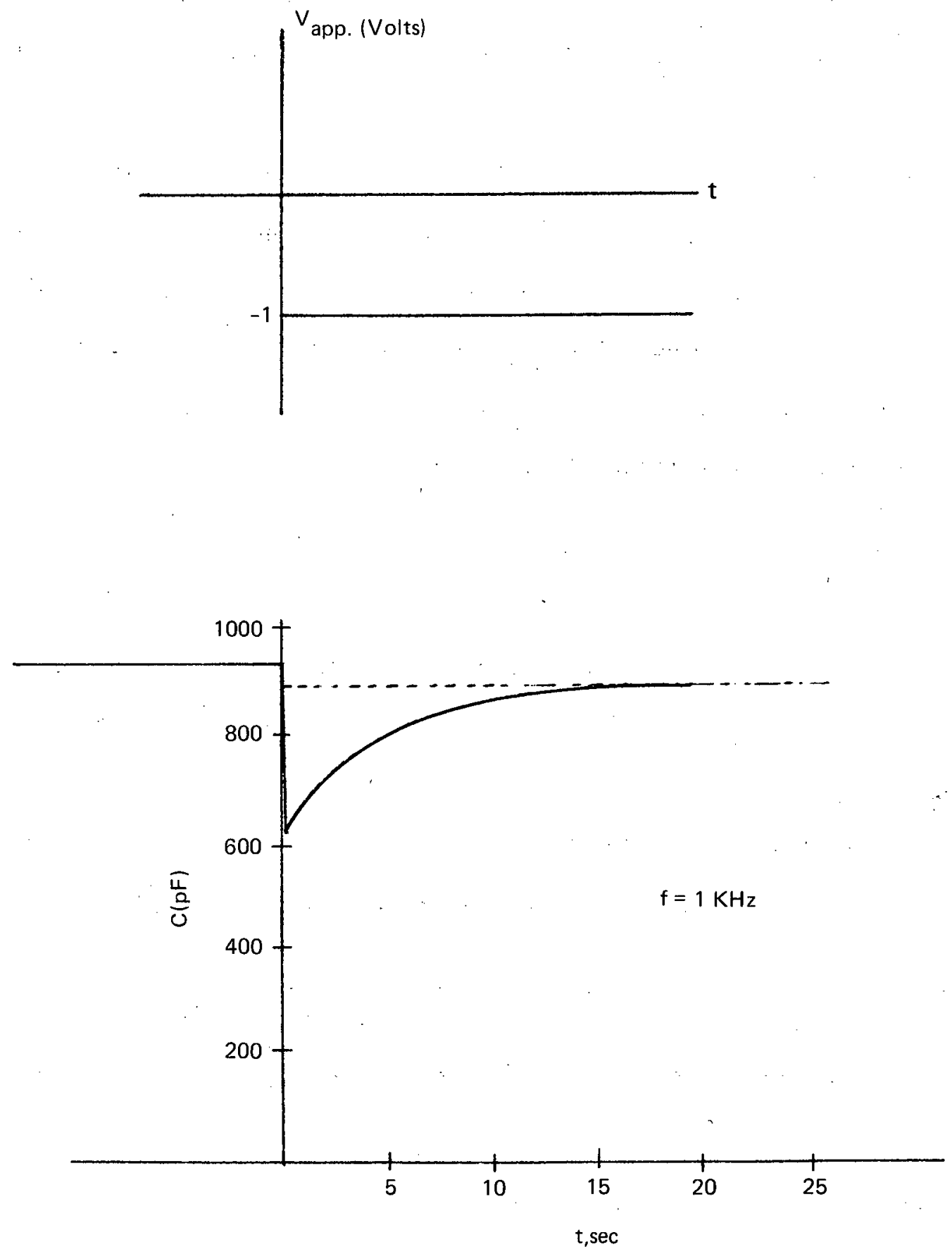

Figure 6. Transient Capacitance Measurement of Diode \#4

$$
-16-
$$


On the other hand, change of the value of the capacitance with the frequency suggests that there are more than one shallow levels distributed in energy between the conduction band and the Fermi levels. Each level can respond to different frequencies, the shallowest being the fastest. Further work is in progress to characterize those levels.

Presence of traps in CdTe is a very well established fact. Experiments performed on single crystal material gave a spectrum of deep levels as is shown in Fig. 7. (4) It is suspected that a band of trapping levels at $\sim 0.5-0.9 \mathrm{eV}$ from the conduction band is dominating in electroplated CdTe films. Further understanding of these levels is essential since their effects on solar cell performance is important.

\section{B. Structura1}

CdTe films plated at different potentials have been investigated by scanning electron microscopy and electron microprobe analysis. The studies showed the presence of particles/crystallites on the smooth surface of the CaTe film that varied in density and size with plating potential. SEM micrographs at different plating potentials are given in Fig. 8. Particle size decreases with increasing plating potential as is summarized in Table II.

\begin{tabular}{|c|c|}
\hline Plating Potential & $\begin{array}{c}\text { Average Particle Size } \\
\text { in Microns }\end{array}$ \\
\hline$-300 \mathrm{mV}$ & - \\
$-400 \mathrm{mV}$ & 5.7 \\
$-550 \mathrm{mV}$ & 5.0 \\
$-600 \mathrm{mV}$ & 1.0 \\
\hline
\end{tabular}

TABLE II

SURFACE PARTICULATE SIZE AS A FUNCTION OF PLATING POTENTIAL 

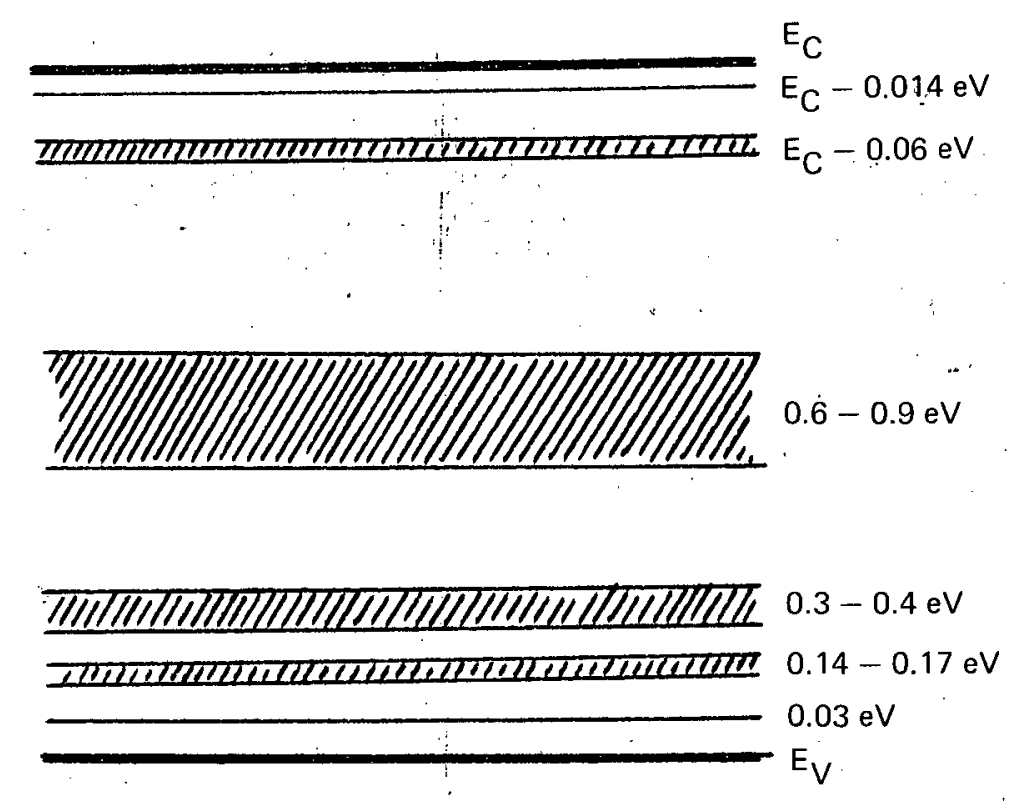

Figure 7. Typical Trapping Levels for Single Crystal CdTe 


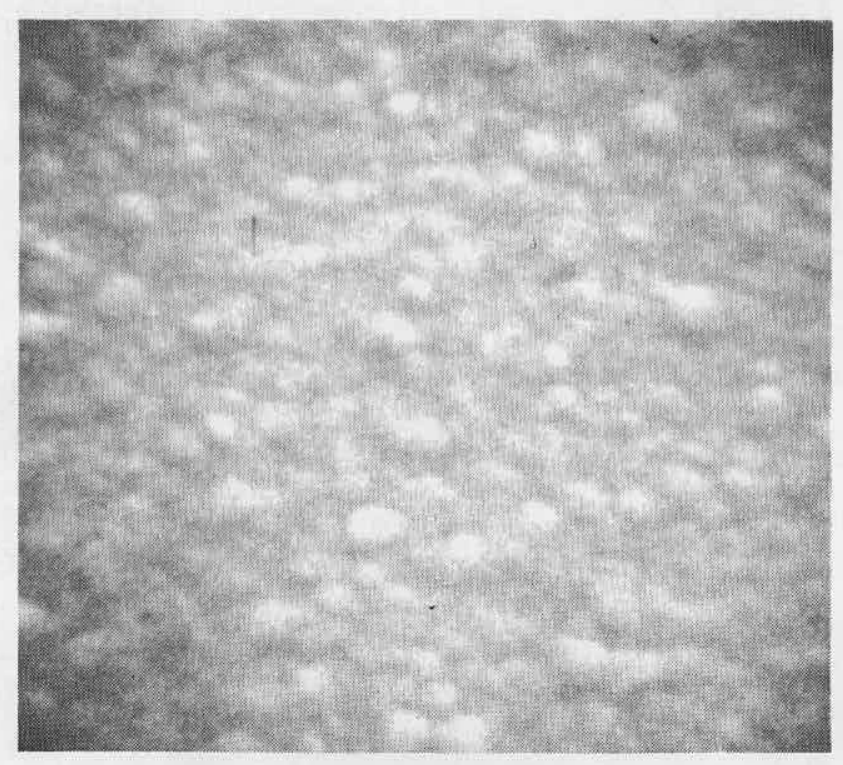

$-300 m V(X 4100)$

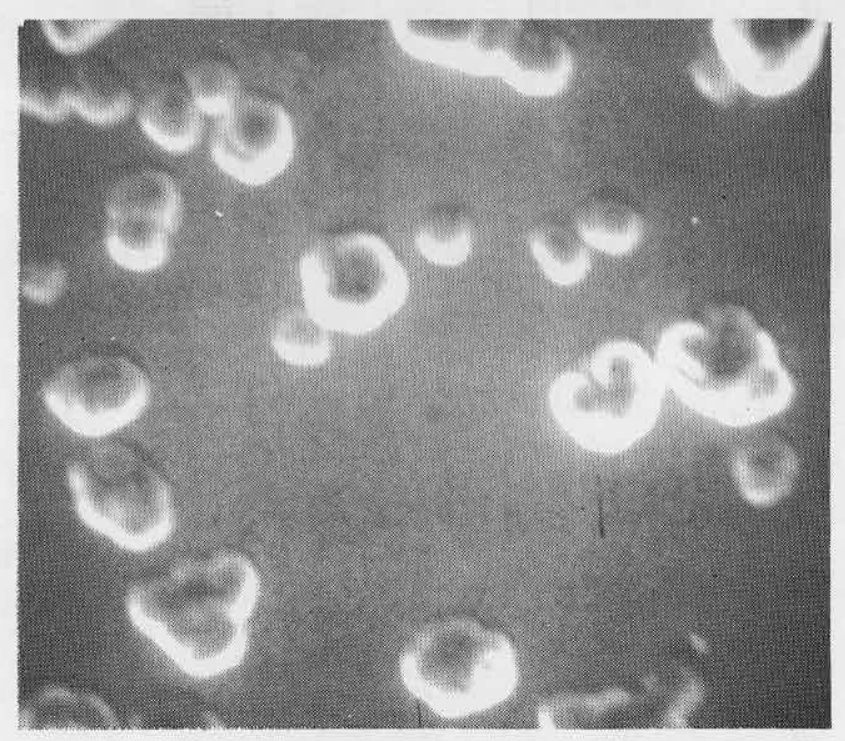

$-550 \mathrm{mV}(\mathrm{X} 1600)$

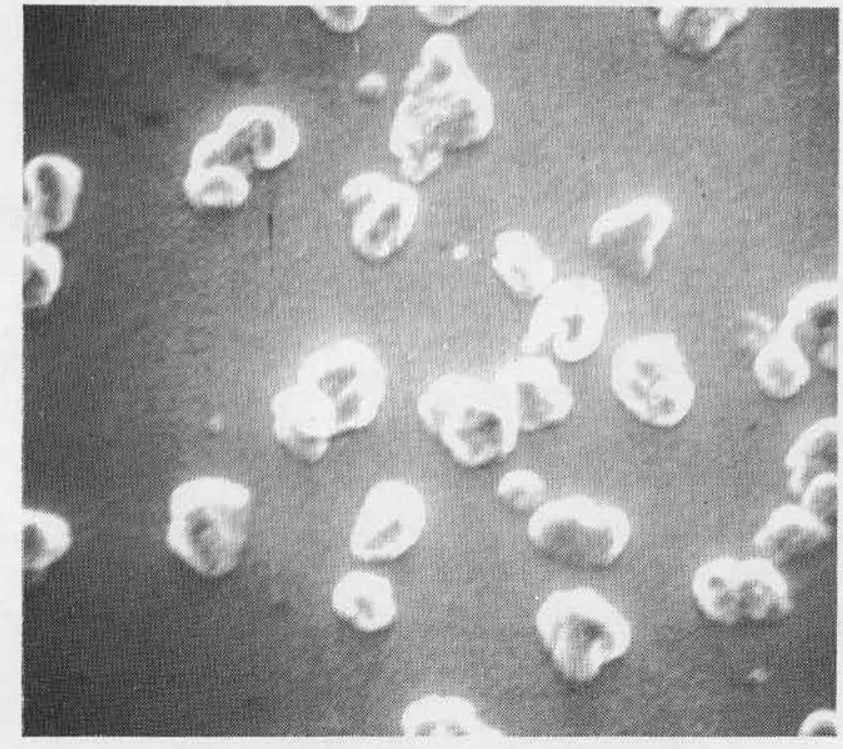

$-400 \mathrm{mV}(\mathrm{X} 1000)$

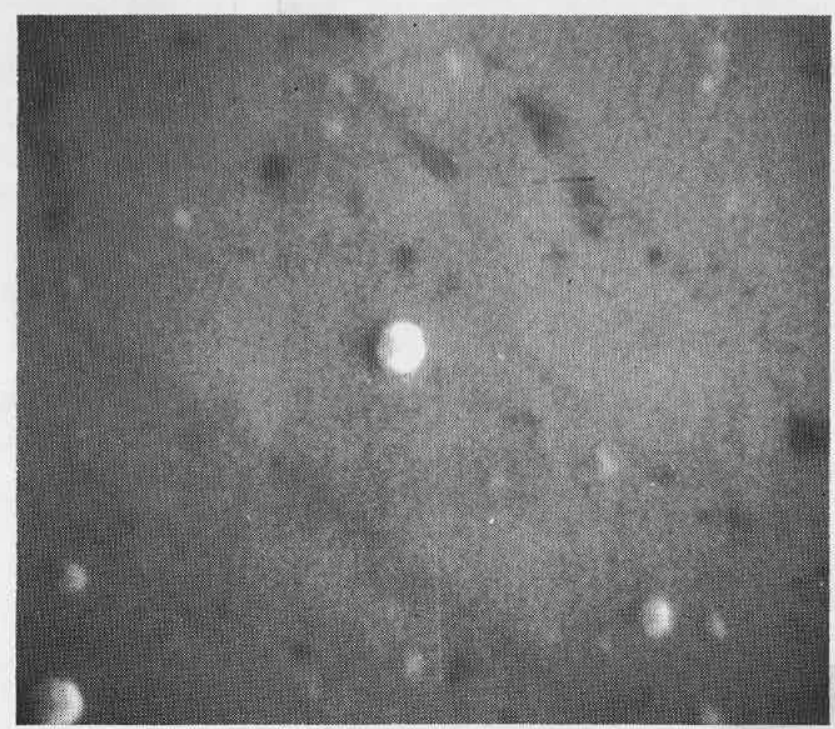

$-660 \mathrm{mV}(\mathrm{X} 4200)$

Figure 8. Surface Particulates as a Function of Plating Potentials 
In order to characterize these heretofore unknown particles, energy dispersive $x$-ray analysis (EDAX) was carried out on a SEM. The studies indicated that the particles are made up of $\mathrm{Cd}$ and Te as shown from the EDAX spectra in Fig. 9. The film surface and the particles showed identical EDAX spectra indicating identical composition for the particles and the film. In order to evaluate the changes in CdTe film stoichiometry as a function of plating potential, electron microprobe analysis was performed on CdTe films deposited at different plating potentials. The studies show that the $\mathrm{Cd} / \mathrm{Te}$ ratio in the films can be changed by as much as $7-8 \%$ by varying the plating potential from -300 to $-700 \mathrm{mV}$. The non-normalized Cd/Te ratio as a function of plating potential is shown in Fig. 10. It may be pointed out that the large error bar in specimen plated at $-700 \mathrm{mV}$ is due to the small thickness of this film as compared to the others.

This report of structural characterizations performed during the first quarter of the present program is best concluded by referring to Figs. 11 and 12 showing the definite polycrystalline structure of electroplated CdTe films made by Monosolar. Fig. 11 is a transmission electron micrograph of CdTe film stripped from a nickel substrate at a magnification of 30,000 . The average particle size of CdTe grains ranges from 0.1 to $0.2 \mu \mathrm{M}$ although many much larger grains in the order of $1 \mu \mathrm{M}$ can also be observed. Fig. 12 is a scanning electron micrograph of a similar sample to that shown in Fig. 11. Surface topography of the order of $1 \mu \mathrm{M}$ is observed. To verify the previous SEM and TEM analyses, transmission electron diffraction patterns were taken for the sample shown in Fig. 12. These are shown in Fig. 13 which gives a value of $0.07 \mu \mathrm{M}$ for smaller grains and in Fig. 14 which shows a $1 \mu \mathrm{M}$ grain size for the larger particles. 
PHA11 ADD O1OKEV/EH

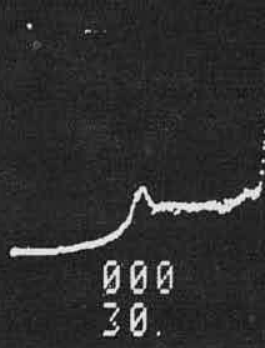

FHA11. ADO G1GKEV/CH $E \| G=$ BIGKE.

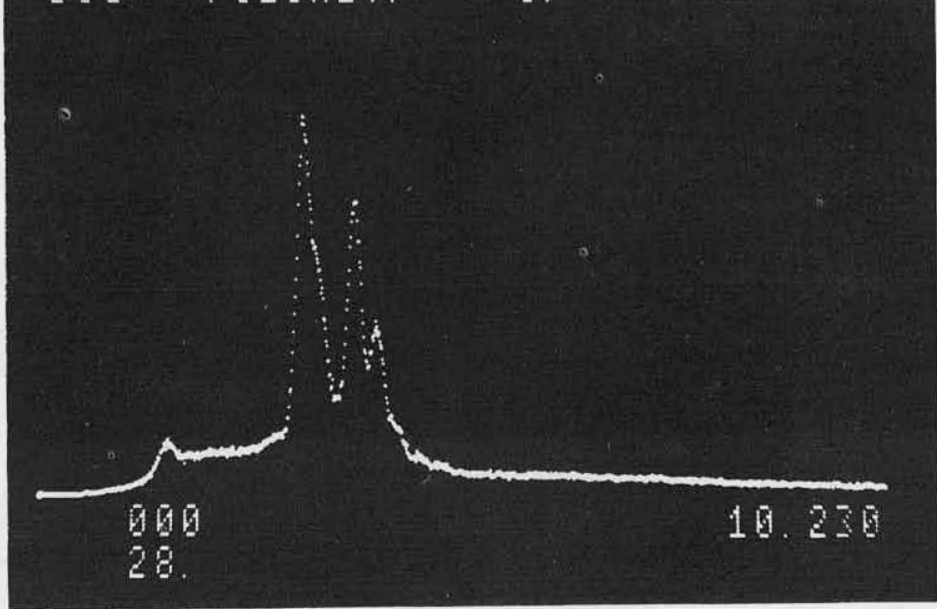

EDAX

Figure 9. EDAX Analysis of Surface Particulates 


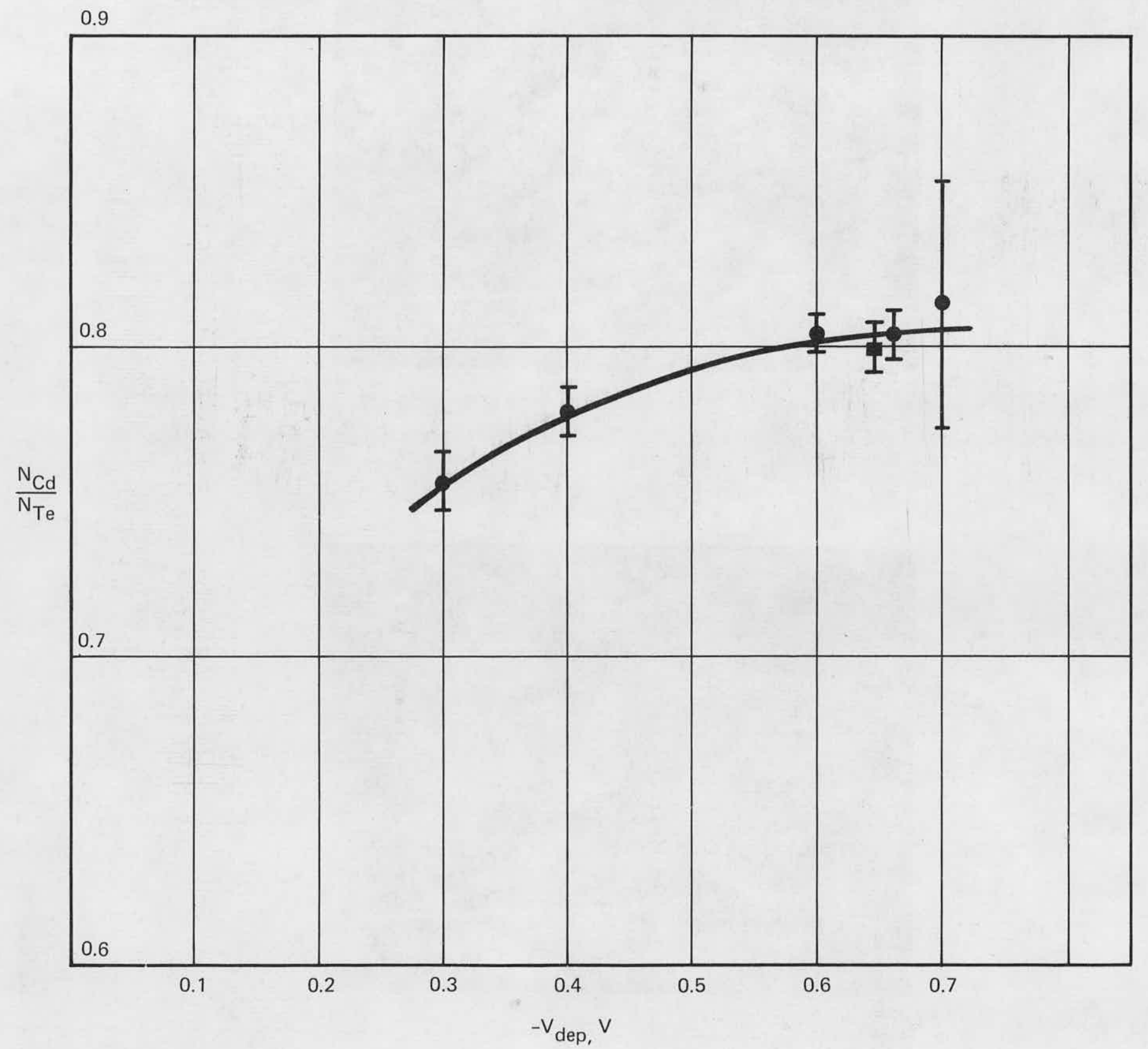

Figure 10. Microprobe Analysis of CaTe Film as a Function of Plating Potential

$-22-$ 


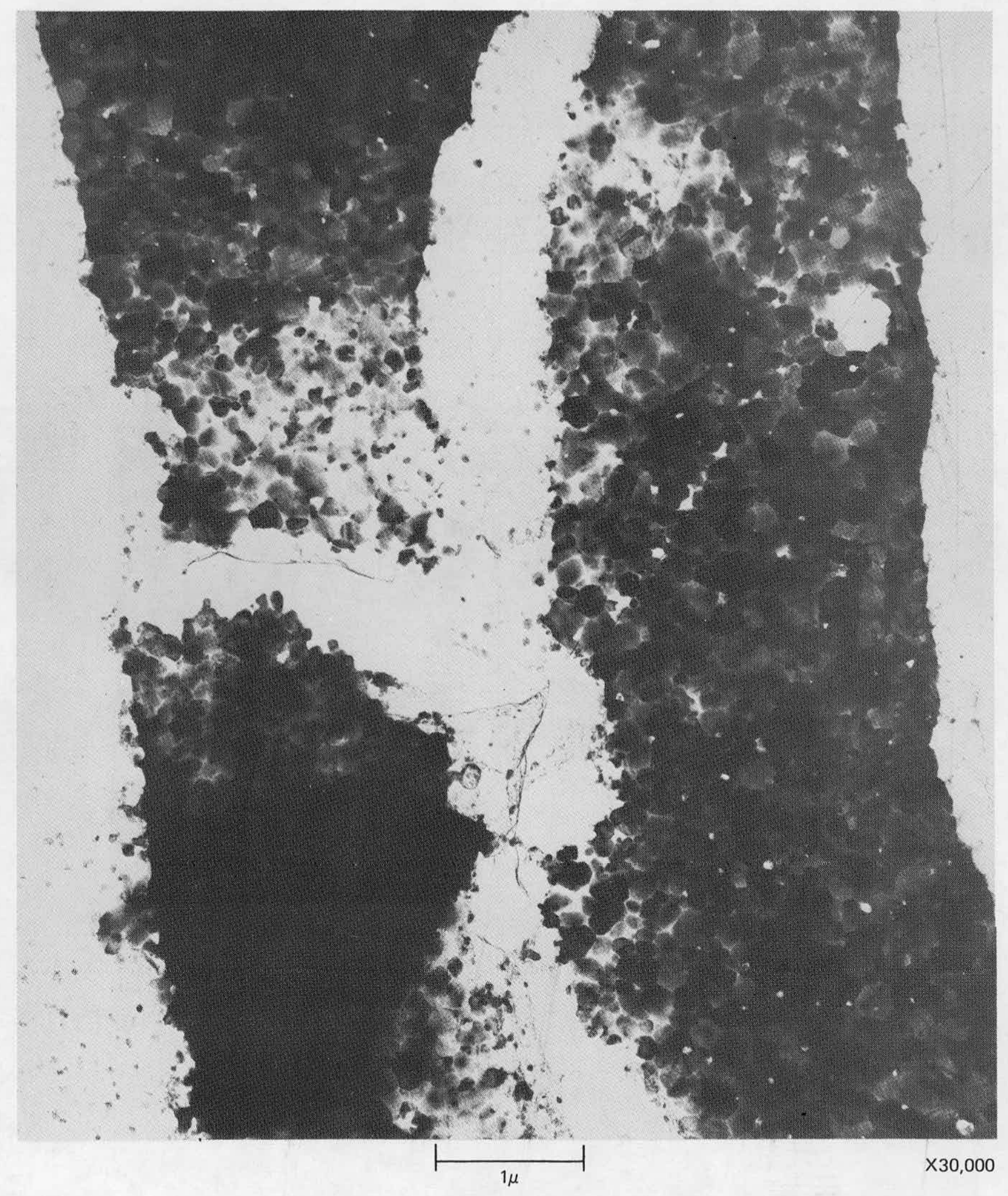

Figure 11. CdTe - Film Stripped from Nickel Substrate 


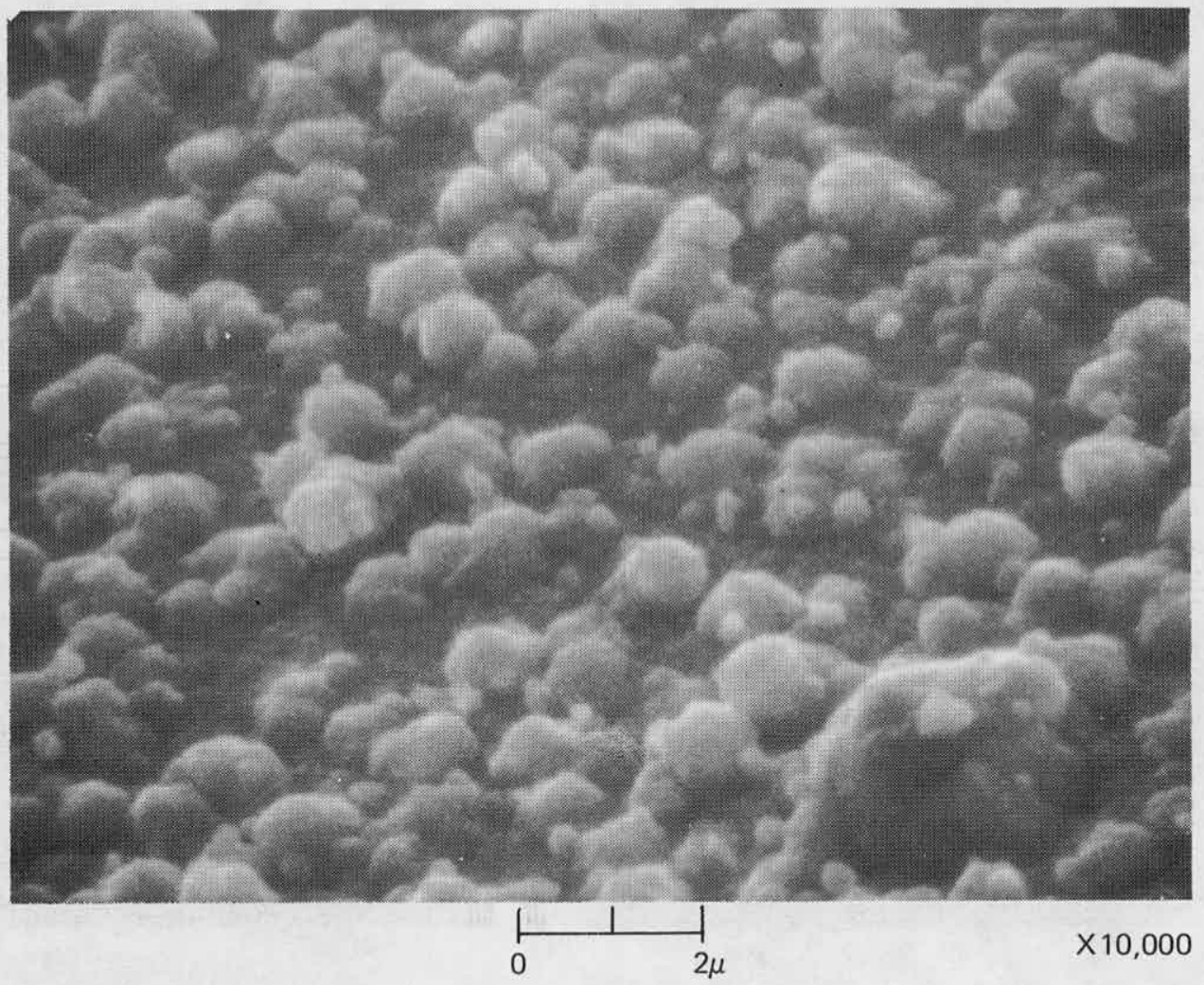

Figure 12. SEM of CdTe Film Surface 

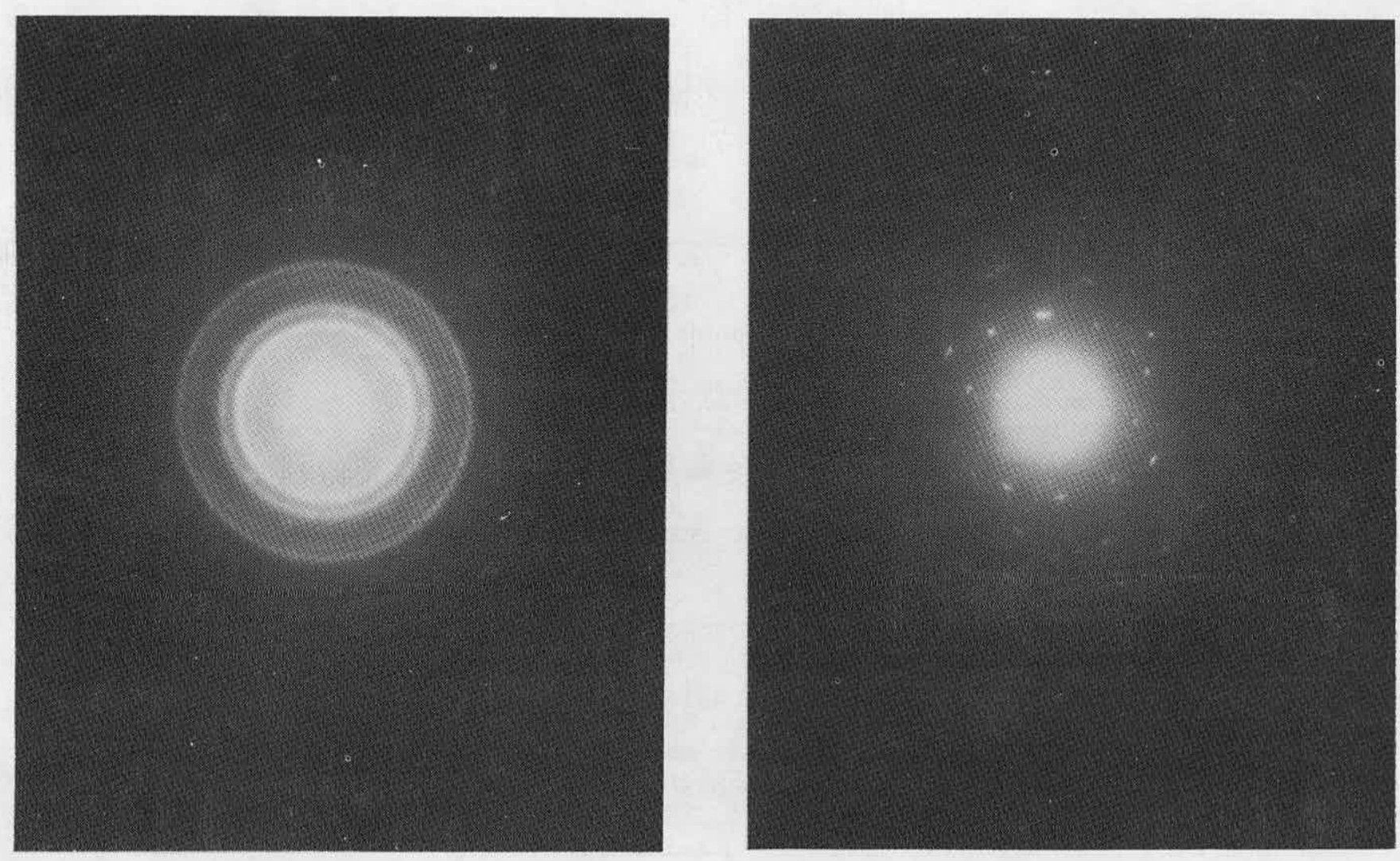

Figure 13.

$0.07 \mu \mathrm{M}$

Figure 14.

$1 \mu \mathrm{M}$

Transmission Electron Diffraction Patterns of CdTe Film Shown in Fig. 12 
It can be concluded, then, that the Monosolar plating process is indeed capable of electroplating a polycrystalline film of CdTe in a relatively low temperature production process $\left(90^{\circ} \mathrm{C}\right)$ up to a thickness of $1 \mu \mathrm{M}$ (and more if needed) with grains measuring up to $1 \mu \mathrm{M}$. Stoichiometry control is a function of the applied plating potential which also affects grain size and device performance.

\section{PREPARATION OF TRANSPARENT CONDUCTING OXIDE FILMS}

As the initial effort, thin transparent conducting films of Indium Oxide $\left(\operatorname{In}_{2} \mathrm{O}_{3}\right)$ and Indium Tin Oxide (ITO), $\operatorname{In}_{2} \mathrm{O}_{3}: \mathrm{Sn}$ were prepared by a new deposition technology. The deposits were characterized by optical transmission, x-ray diffraction and sheet resistance measurements. The details are given in Appendix I.

V. WORK PROPOSED DURING UPCOMING QUARTER

Efforts underway at this writing that will be discussed in the next quarterly report are best given in tabular form:

1. Reduction of contamination in electrolytes and reagents

2. Development of ohmic contacts to $\mathrm{CdTe}$

3. Thermal and possibly laser annealing of CdTe films

4. Optimization of co-deposition of dopants

5. Construction of operative ITO/CdTe solar cells as required in the Work Statement for submission to DOE/SERI 


\section{REFERENCES}

(1) "Development of Large Area Solar Cells Based on CdTe", Monosolar Fina1 Report, DOE Contract No. EX-76-C-01-2457, July 15, 1978.

(2) C. T. Sah, L. Forbes, L. L. Rosier and A. F. Tasch, Jr., Solid State Electron, 13, 759 (1970).

(3) Furukawa, Y. Ishibashi, Japan J. App1. Phys., 6, 503 (1967).

(4) K. Zanio, "Semiconductors and Semimeta1s", edited by R. K. Willardson, A. C. Beer, V. 13, p. 162 . 
Preparation of $\operatorname{In}_{2} \mathrm{O}_{3}$ and Sn-doped

$I_{2}{ }_{3}$ Films by a Novel Activated

Reactive Evaporation Technique

P. Nath and R. F. Bunshah

Materials Department

University of California

Los Angeles, CA 90024

ABSTRACT:

High quality films of $\operatorname{In}_{2} \mathrm{O}_{3}$ and Sn-doped $\operatorname{In}_{2} \mathrm{O}_{3}$ have been prepared by a novel activated reactive evaporation technique. Transparent conducting coatings of $\operatorname{In}_{2} \mathrm{O}_{3}$ have sheet resistance of 80-100 $\Omega / a$ with an optical transparency of $95 \%$ in the wavelength range of 0.4 to $1.6 \mu \mathrm{m}$. $\operatorname{In}_{2} \mathrm{O}_{3}:(\mathrm{Sn})$ films have sheet resistance of 20-30 $\Omega / 0$ and have an optical transparency as high as $99 \%$ at some wavelengths and an average transmission of $97 \%$ between 0.4 and $1.6 \mu \mathrm{m}$. A comparison of the performance of $\mathrm{In}_{2} \mathrm{O}_{3}:(\mathrm{Sn})$ films with the transparent conducting films produced by other techniques is made. 
Transparent electrically conducting thin films of various oxides (e.g. $\mathrm{SnO}_{2}, \mathrm{In}_{2} \mathrm{O}_{3}:(\mathrm{Sn}), \mathrm{Cd}_{2} \mathrm{SnO}_{4}$ ) have attracted considerable attention in recent years because of their use in photovoltaic heterojunction solar cells. To date, the best transparent conducting films are obtained either by chemical vapor deposition (hydrolysis of chlorides or pyrolysis) or sputtering (reactive sputtering from an oxide target). The status of various conducting oxide coatings, prepared by different techniques has been summarized recently by Vossen $(1)$ and Haacke. (2) This appendix reports on the preparation of high optical quality transparent conducting films of $\mathrm{In}_{2} \mathrm{O}_{3}$ and $\mathrm{Sn}$ doped $\mathrm{In}_{2} \mathrm{O}_{3}$ films by a novel plasma activated reactive evaporation technique.

Figure 1 shows schematically the experimental setup. An oil diffusion pump equipped with a liquid $\mathrm{N}_{2}$ trap was used to achieve a base pressure of $<2 \times 10^{-6}$ torr. A resistively heated tungsten/tantalum source was used for evaporating In or In-Sn alloys. The substrates were mounted on a substrate table and can be maintained at temperatures ranging from 25 to $500^{\circ} \mathrm{C}$. A mixture of $\mathrm{Ar}+\mathrm{O}_{2}$, used as a reactive gas was bled into the system by a calibrated leak valve. The pressure during deposition was maintained at $1 \times 10^{-4}$ torr. In order to enhance the reactivity of the In/In-Sn vapor species with the reaction gas, a dense plasma was generated by employing a thoriated tungsten emitter and a low voltage anode assemb1y. Magnetic field coils were used to confine the plasma and further enhance the reaction.

The films were prepared by evaporating In (99.999\%) and In-Sn(10-20at.\%) onto chemically cleaned glass and quartz substrates. The deposition rate was $0.04 \mu \mathrm{m} / \mathrm{min}$ and typical thickness was $\sim 0.4 \mu \mathrm{m}$. The substrate temperature was kept at $350^{\circ} \mathrm{C}$. The crystallographic structure of the films wais analyzed by $x$-ray diffraction. The optical transmittance is measured as a function of 
wavelength between 0.3 and $1.8 \mu \mathrm{m}$. The sheet resistance and electrical resistivity were measured by a conventional four probe arrangement.

Bulk $\operatorname{In}_{2} \mathrm{O}_{3}$ crystallizes in a cubic $\mathrm{Tl}_{2} \mathrm{O}_{3}$ bixbyte structure. (3) X-ray diffractometer measurements on pure $\operatorname{In}_{2} \mathrm{O}_{3}$ and doped $\operatorname{In}_{2} \mathrm{O}_{3}:(\mathrm{Sn})$ films revealed a similar structure. X-ray diffractograms for a pure $\mathrm{In}_{2} \mathrm{O}_{3}$ and $\mathrm{In}_{2} \mathrm{O}_{3}$ : (Sn) (18at.\%) films are shown in Fig. 2。 In the $\operatorname{In}_{2} \mathrm{O}_{3}$ : (Sn) films no $\mathrm{SnO}_{2}$ phase was detected implying Sn replaces In substitutionally in the bcc lattice. This observation is in accordance with the observation of a large number of workers ${ }^{(4-8)}$ on these films prepared by different techniques. As revealed by the intensity distribution of the $x$-ray diffraction pattern, whereas, pure $\mathrm{In}_{2} \mathrm{O}_{3}$ films show a preferred orientation in the (100) direction, $\mathrm{In}_{2} \mathrm{O}_{3}:(\mathrm{Sn})$ films have (111) preferred orientation. A (111) orientation in sputtered $(5,9)$ and $\mathrm{CVD}^{(7,8)}$ films has been reported in the 1iterature. Vossen ${ }^{(4)}$ has also reported (100) preferred orientation in his sputtered films. It may be pointed out that the preferred orientation depends on the deposition conditions.

Figure 3 shows the transmittance as a function of wavelength for $\operatorname{In}_{2} \mathrm{O}_{3}$ and $\operatorname{In}_{2} \mathrm{O}_{3}:(\mathrm{Sn})$ films. It is seen that both $\operatorname{In}_{2} \mathrm{O}_{3}$ and $\operatorname{In}_{2} \mathrm{O}_{3}:(\mathrm{Sn})$ show identical behavior and a rapid transmittance increase to value of .95 at $0.4 \mu \mathrm{m}$ wavelength. The average transmittance is .96-.97 from 0.4 to $0.6 \mu \mathrm{m}$, beyond which it decreases slowly. From the T vs. $\lambda$ curve the absorption edge for these films is seen to be at $0.35 \mu \mathrm{m}(3.54 \mathrm{eV})$. Table I summarizes the electrical and optical properties of $\operatorname{In}_{2} \mathrm{O}_{3}$ and $\operatorname{In}_{2} \mathrm{O}_{3}:(\mathrm{Sn})$ films. It is seen that the films with a sheet resistance of $25 \Omega / D$ have an average transmittance of 97. It may be pointed out that the film thickness is $\approx .0 .4 \mu \mathrm{m}$ and by sacrificing few percent on transmittance, films with lower sheet resistance have been made. 
It would be useful to compare the performance of the $\operatorname{In}_{2} \mathrm{O}_{3}:(\mathrm{Sn})$ films prepared by this "Activated Reactive Evaporation" technique with the conducting transparent coatings prepared by other techniques. The results for different types of coatings prepared by a variety of techniques such as pyrolysis, CVD, reactive sputtering, the sputtering of oxide targets are summarized in Table II. Also given are the values of "figure of merit" $\left(\mathrm{T}^{10} / \mathrm{R} \Omega\right){ }^{(10)}$ for the various coatings. It is seen that $\operatorname{In}_{2} \mathrm{O}_{3}:(\mathrm{Sn})$ films prepared by our technique clearly demonstrate much better optical characteristics. The films have an optical transparency of 0.99 at certain wavelengths and over 0.95 even up to wavelengths as high as $1.6 \mu \mathrm{m}$. Apart from this, whereas, our technique involved no post deposition treatment, all the films reported receive some kind of post deposition treatment involving temperatures as high as $400-700^{\circ} \mathrm{C}$ in a variety of ambients.

In conclusion we have demonstrated that the "Activated Reactive Evaporation" technique is capable of producing high optical quality transparent conducting films of $\mathrm{Sn}$-doped $\operatorname{In}_{2} \mathrm{O}_{3}:(\mathrm{Sn})$. Apart from this, the absence of any post deposition heat treatment (a requirement of conventional evaporation arrangement) and short deposition times make this technique an attractive economical manufacturing technique for producing transparent conducting films for use in display storage devices, heterojunctions and a variety of other applications. 


\section{REFERENCES}

(1) J. L. Vossen, Physics of Thin Films, Eds. G. Hass, M. H. Francombe and R. W. Hoffman, Vol. 9, 1 (1977) Academic Press N. Y.

(2) G. Haacke, Ann. Rev. Mater. Sci. 7, 73 (1977).

(3) R. W. G. Wyckoff, "Crystal Structures", 2nd Ed., Vol, 1-3, Wiley, Interscience N. Y. (1963).

(4) J. L. Vossen, R.CA Rev. 32, 289 (1971).

(5) M. Hecq, A. Dubois and J. Van Cakenberghe, Thin Solid Films, 10, 117 (1973).

(6) J. R. Bosnell and R. Waghorne, Thin Solid Films, 15, 161 (1973).

(7) H. Küstlin, R. Jost and W. Lens, Phys. Stat. Sol. 29a, 87 (1975).

(8) J. C. Manifacier, L. Szepessy, J. F. Bresse, M. Perotin and R. Stuke, Mat. Res. Bul1. 14, 109 (1979).

(9) D. B. Fraser and H. D. Cook, J. Electrochemical Soc., 119, 1368 (1972).

(10) G. Haacke, J. App1. Phys. 47, 4086 (1976).

(11) D. M. Mattox, J. Vac. Sci. Tech., 12, 5, 1023 (1975).

(12) J. C. Manifaciar, L. Szepessy, J. E. Bresse, M. Perotin and R. Stuke, Mat. Res. Bu11. 16, 163 (1979).

(13) G. Haacke, W. E. Mealmaker and L. A. Siege1, Thin Solid Films, 55, 67 (1978). 
Film

$\operatorname{In}_{2} \mathrm{O}_{3}$

$\operatorname{In}_{2} \mathrm{O}_{3}:(\mathrm{Sn})$
Sheet Resistance (ohm/Q)

25

90
Integrated Trans-

mittance over $0.4-1.6 \mu \mathrm{m}$

0.96

0.96

TABLE I 


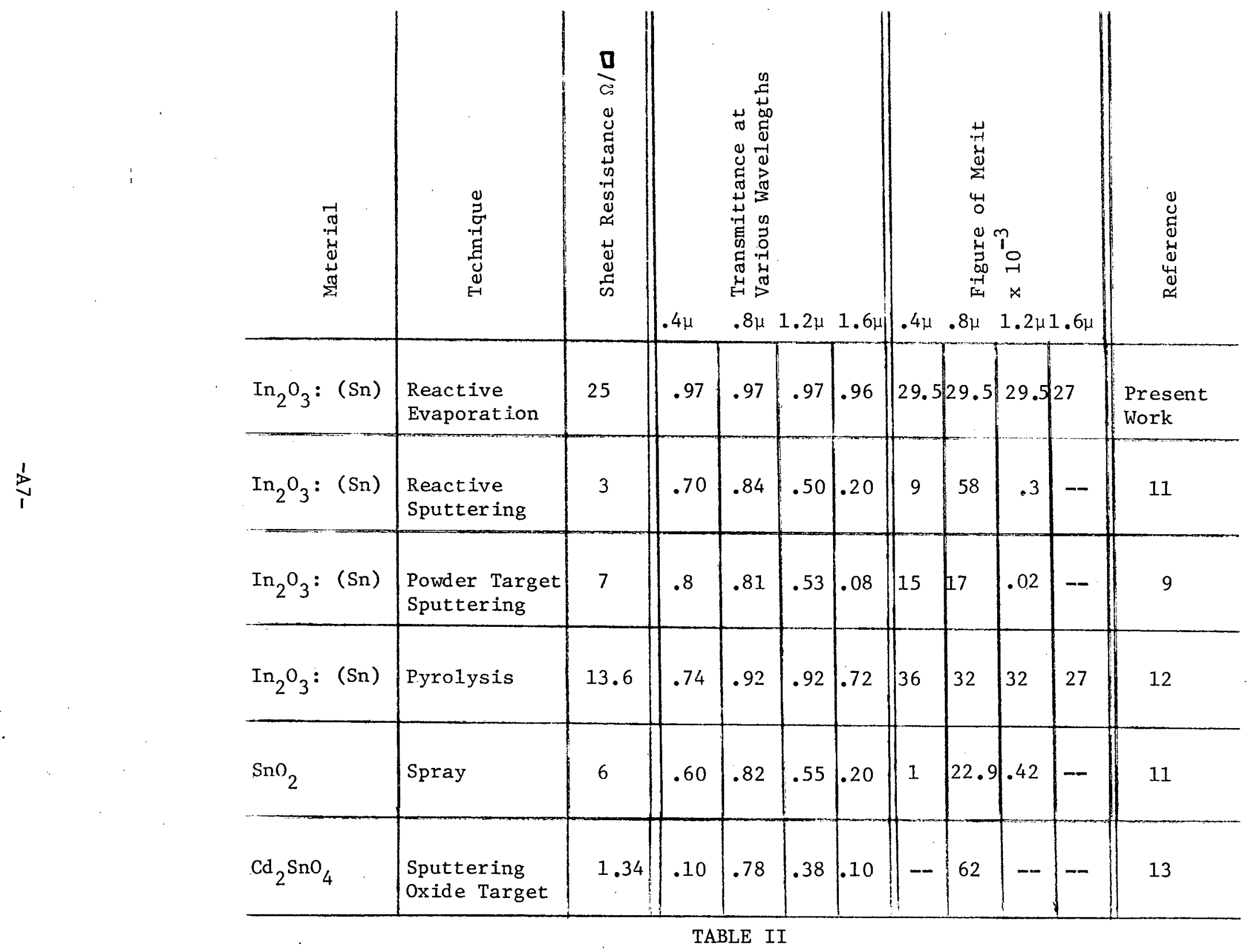




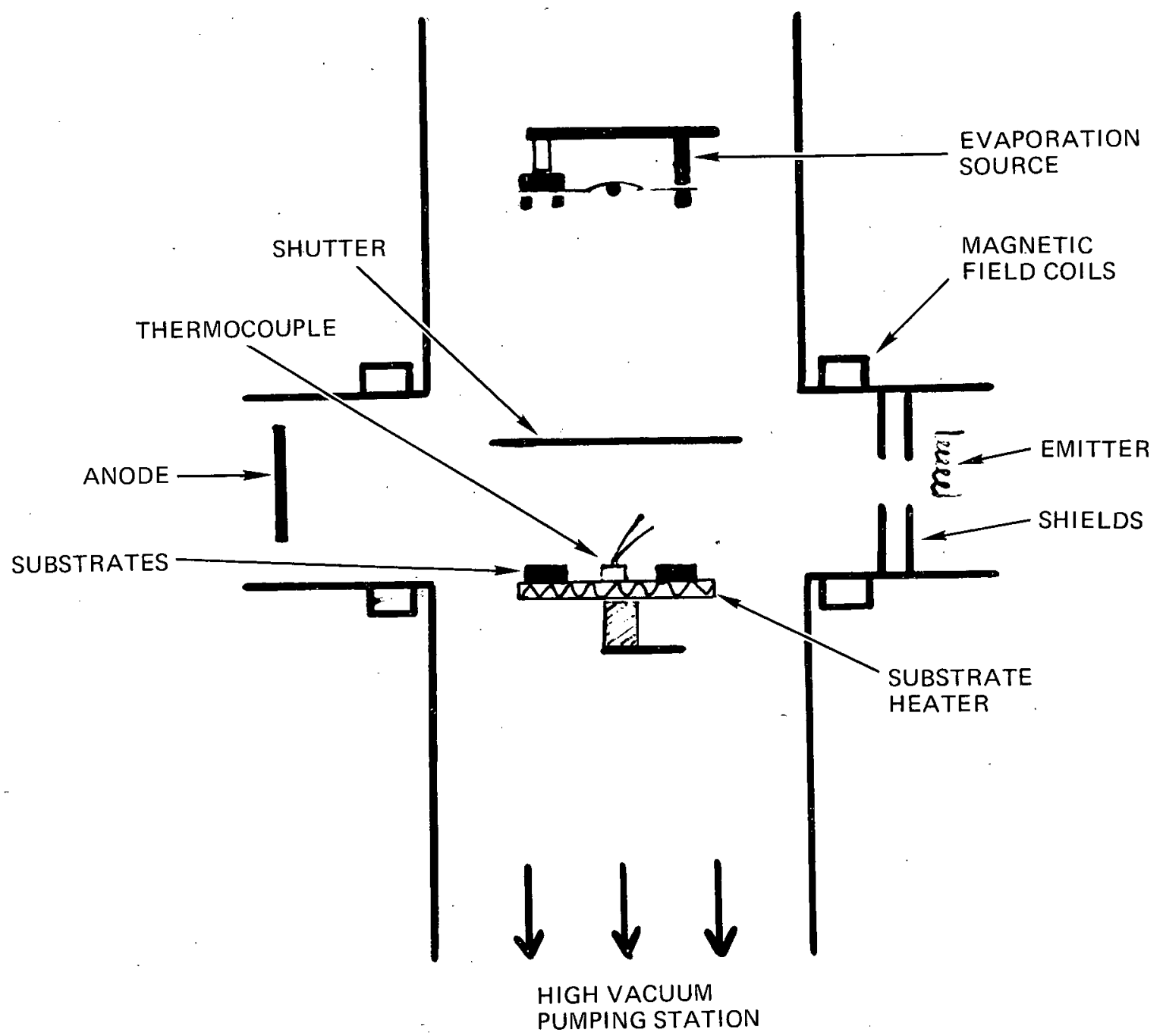

Figure 1. Schematic Diagram of the Experimental Setup for Activated Reactive Deposition of $\operatorname{In}_{2} \mathrm{O}_{3}$ and $\operatorname{In}_{2} \mathrm{O}_{3}(\mathrm{Sn})$ Films 


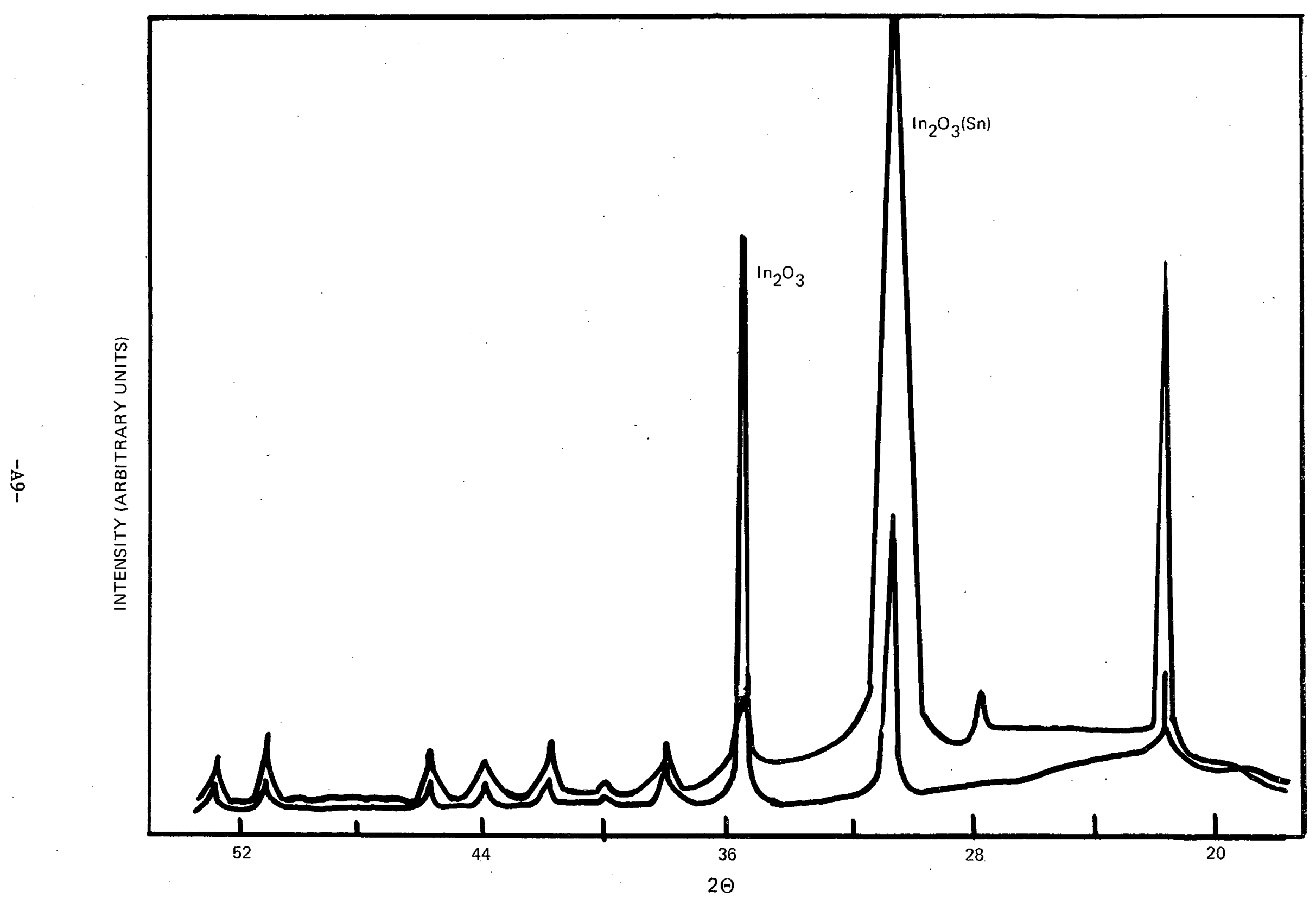

Figure 2. X-Ray Diffractograms of $\operatorname{In}_{2} \mathrm{O}_{3}$ and $\operatorname{In}_{2} \mathrm{O}_{3}(\mathrm{Sn})$ Films 


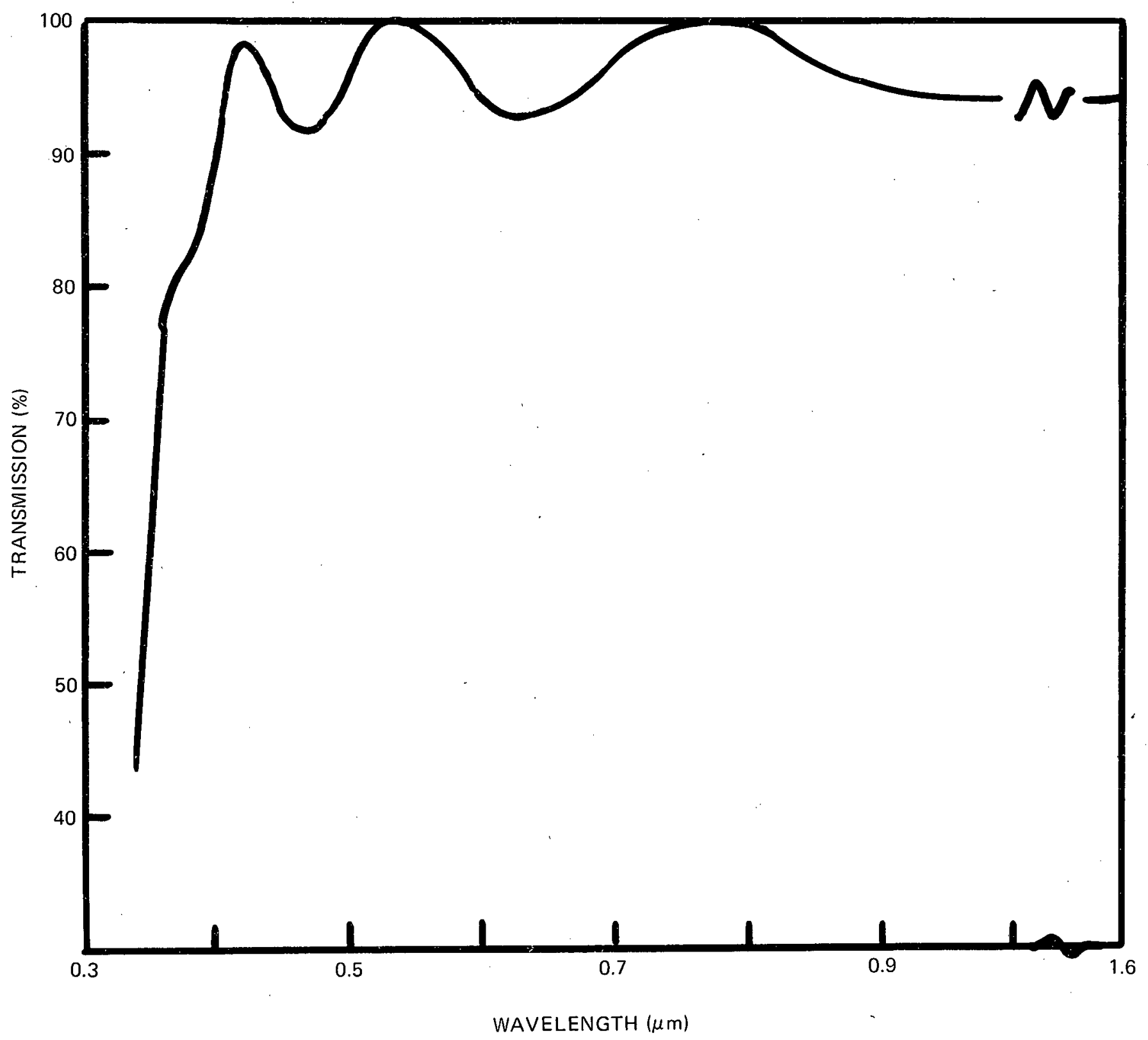

Figure 3. Transmission as a Function of Wavelength for a $\operatorname{In}_{2} \mathrm{O}_{3}(\mathrm{Sn}) \mathrm{Film}$ 